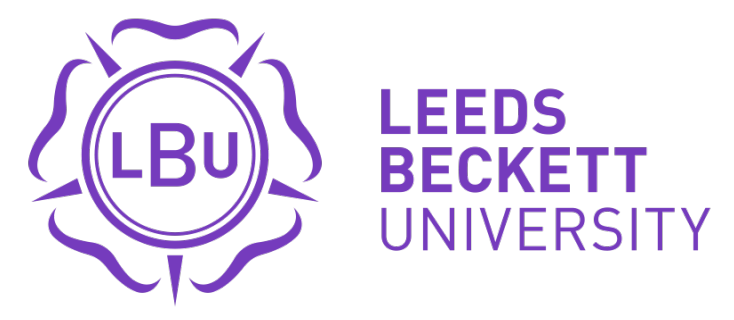

Citation:

Ivanova, M (2017) The inclusion of the communist/socialist heritage in the emerging representations of eastern Europe: The case of Bulgaria. Tourism, Culture and Communication, 17 (1). pp. 31-46. ISSN 1098-304X DOI: https://doi.org/10.3727/109830417X14837314056852

Link to Leeds Beckett Repository record:

https://eprints.leedsbeckett.ac.uk/id/eprint/4115/

Document Version:

Article (Published Version)

Creative Commons: Attribution-Noncommercial-No Derivative Works 4.0

The aim of the Leeds Beckett Repository is to provide open access to our research, as required by funder policies and permitted by publishers and copyright law.

The Leeds Beckett repository holds a wide range of publications, each of which has been checked for copyright and the relevant embargo period has been applied by the Research Services team.

We operate on a standard take-down policy. If you are the author or publisher of an output and you would like it removed from the repository, please contact us and we will investigate on a case-by-case basis.

Each thesis in the repository has been cleared where necessary by the author for third party copyright. If you would like a thesis to be removed from the repository or believe there is an issue with copyright, please contact us on openaccess@leedsbeckett.ac.uk and we will investigate on a case-by-case basis. 


\title{
THE INCLUSION OF THE COMMUNIST/SOCIALIST HERITAGE IN THE EMERGING REPRESENTATIONS OF EASTERN EUROPE: THE CASE OF BULGARIA
}

\author{
MILKA IVANOVA \\ Events, Tourism and Hospitality School, Carnegie Faculty, Leeds Beckett University, Leeds, UK
}

\begin{abstract}
After the fall of the Iron Curtain and the end of the communist/socialist regimes many Eastern European countries sought to establish new separate, unique identities as part of the Western World and the European political and economic organizations. The old totalitarian identities, histories, and heritages have mostly been excluded from the desired and preferred representations about and of these countries and in many instances even silenced and suppressed. Tourism as major creator and mediator of knowledges and images about places, peoples, and pasts is an important factor in these processes of identity making, inclusion, and exclusion. In the case of Bulgaria, the communist/socialist heritage has been marginalized and silenced in the past 20 years as the country's new European identity has been made, established, mediated, and announced. However, in the past 5 or so years with the hardships of the transitional period still continuing and with an emerging sense of nostalgia towards the socialist/communist period, the totalitarian heritage has slowly started to become visible in the public discourse. Moreover, there has been registered desire by authoritative agents in the country to revisit that part of the Bulgarian history and include it through heritage sites in the exhibited and represented images of Bulgaria including through/in tourism. The proposed article offers an examination of these slow and contested processes of inclusion of the communist/socialist heritage and how this inclusion (or continued exclusion) is the interplay of power, identity, and tourism. These issues are examined within the context of a qualitative critical interpretive study of Bulgaria.
\end{abstract}

Key words: Totalitarian; Communist; Heritage; Identity; Representation; Silences; Power

Introduction

Bulgaria has undergone significant changes in the past 20 years; changes that to a large extent are still ongoing (Brzezinski, 1993). The falling apart of the Soviet Union and its satellite East European countries brought about transformations not only in the political and economic system of Bulgaria but also in the country's society and culture (Baeva \& Kalinova, 2003). From the Western perspective, 
the country, from a relatively unknown (or known as just as a Russian clone) communist/socialist state, became an even less known state in transition to democracy (Bojkov, 2004). With the fall of the "Iron Curtain," the slow emergence of free speech, and the curiosity of Western countries towards the processes in Bulgaria and the other former Soviet bloc countries, Bulgaria became more familiar to the European countries. This process of introduction/reintroduction was sped up with the desire of Bulgaria to join NATO, and the EU-a membership to these structures would mean the long transitional period was over, and the country had become a democratic member of the European and World communities.

The transitional period that in many ways is still ongoing has not been an easy one for Bulgaria. The initial exhilaration about the fall of the Berlin Wall and communism in Eastern Europe in general both in the country and in the West was quickly replaced by fear and insecurity for the future. There was growing skepticism of the ability of the newly emerged countries to cope with and manage the necessary changes and close the gap between themselves and their Western neighbors (Baeva \& Kalinova, 2003; Brzezinski, 1993; Lavigne, 2000). That skepticism was reinforced by the situation in Bulgaria-the spreading of corruption, the appearance of structures (outside the lawfully created and sanctioned ones), the delay in the necessary changes, the collapse of the economic and financial structures, the proliferation of unemployment, and the sharp rise in immigration (Anderson, Wiessala, \& Williams, 2000). All these problems led to serious doubts that Bulgaria should join the EU (Bojkov, 2004). The succession of Bulgarian governments took serious measures to change not only the situation in the country but also the perception of the country in the West. These attempts continue today with Bulgaria being an EU member-but an often criticized and severely scrutinized one, in many cases to the opinion of both government and people in an unfair way. These issues have led Bulgaria to attempt to create a more positive image of itself to change the perceptions of its people and the West alike. This desire to present a different image of the country is an expression of deeper issues for the Bulgarian people- the desire to discover/rediscover who they are as a nation, separate from the communist/ socialist indoctrination that went on for 45 years. In many ways, this aspiration to rediscover/reinvent what Bulgaria is and what it is becoming is not unlike the struggles of the postcolonial world to reestablish itself and find new identities free from colonial influences (McNeill, 2004; Venn, 2006). This drive, even restlessness, is happening to all populations, ethnic groups, subcultures, and even nations (Gandhi, 1998).

Bulgaria, like many other populations, in an attempt to legitimize itself (in front of and as a member of the EU), is turning to its roots and authentic precommunist era culture, preserved and passed on through/as tradition (Frusetta \& Glont, 2009; Huggan, 2001). The desire to create and present new privileged understandings and images of Bulgaria by turning to a preferred past and tradition through which the present can be viewed/ understood can be interpreted as an attempt also to establish the right of Bulgaria to "be" in Europe. However, the national identity is based not on "New Europe" (Smith, 2002) but on "old," even "ancient" European country with every right to "belong" in the West (Bianchi, 2002).

Many campaigns and initiatives have been carried out to represent this different image and identity of Bulgaria to the world, such as the "Bulgarian Symbols" initiative (Sibley, Jackson, Atkinson, \& Washbourne, 2005). A lot of them have been largely created/appropriated/driven/made by the tourism industry in Bulgaria. In many cases, this has been a directed and conscious attempt, but sometimes this has been largely multidirectional and subconscious, even unconscious attempts, results, or by products (Harrison, 1993; Pearlman, 1999). Tourism is becoming increasingly important (Jack \& Philips, 2005) for Bulgaria as an industry that brings huge revenues and profits. Its increasing is also seen as a way to (1) legitimate and confirm the social and economic standing of Bulgaria firmly in the EU and to (2) normalize specific views on Bulgarian nationality, heritage, and tradition that are European in their character but still different enough to be a valuable contribution to the European culture and an exciting/undiscovered/even exotic tourist destination (Horne, 1993; Allcock, 1995).

As an emerging tourist destination and as a country in transition, Bulgaria offers an opportunity to look at how certain representations and images are 
interrelated in the context of a Western country that strives to project different preferred, and to a degree aspirational, images of itself through/in tourism. It offers the opportunity to also examine the processes of normalization of certain histories and pasts and the favoring of certain heritages in the representations of the country's being and becoming. It focuses on the ambiguity of the presented images and heritages as symbols of the underlining desired values, norms, and customs that constitute the context of the understanding of the notion of nation and the collective silencing, suppressing, and marginalization of past that no longer express the imagined futures.

In the past few years, Bulgaria has had a rather negative image especially in the Western media but also among the EU institutions. That fact has made creating more positive images of the country a priority for the Bulgarian government (McNeill, 2004). One of the ways to achieve this has been through the advertising of the country as a tourist destination. That is not surprising since the tourism industry is one of the most important industries in Bulgaria with tourism bringing about $15 \%$ of the GBP and tourists arriving from Europe, Russia, and increasingly Asia (Ministry of Economy, Energy and Tourism, 2007). With tourism becoming more and more important for the country not only as an industry but as a vehicle to project desired images (Theobald, 2005) of Bulgaria, it is important to examine is being left out and to what extent the socialist era in Bulgarian history is part of the current normalized narrative.

There is a strong interest towards postcommunist countries, a curiosity of what life used to be behind the mystery of the "Iron Curtain" mixed with nostalgia, and tourists search to engage in what is being termed communist/socialist tourism. At the same time, many of the postcommunist countries are undergoing processes of becoming and normalizing and enunciate images of themselves and their pasts that actively seek to exclude and, as we will see in the case of Bulgaria, destroy heritages and representations of this period.

Consequently, the article aims to explore the role of communist/socialist heritage in emerging representations of Bulgaria and the researcher has derived the following objectives: (1) to critically analyze what constitutes communist/socialist heritage, (2) to identify the main narratives about communist heritage in Bulgaria, and (3) to explore the power dynamics in what comes to be known about the Bulgarian past in the form of heritage.

The rest of the article examines pertinent literature, outlines conceptual and theoretical influences, presents the proposed methodology and the main methodological concerns, identifies and discusses the main emergent themes, and offers a warning regarding the silenced and exhibited heritage of Communist Bulgaria.

\section{Literature Review}

The examined literature looks at three main lines of influence, namely: heritage, tourism, and representation. The focus is on the intersection between the three, heritage as an act of representation of what comes to be known about the past and the role of tourism as creator, conveyor, and curator of such narratives of the past.

Bulgaria has undergone a seismic transition in the past 20 years where the previous norms and values have been seemingly completely replaced, and its culture can be expected to be a lot more flexible, fluid, open, and changeable (Lanfant, Allcock \& Bruner, 1995; Benovska-Sabkova, 2001). Heritage equally is not only the simply defined "interest in the past, interest in cultures, buildings, artefacts and landscapes of both the past and present" (Boyd, 2002, p. 212); it is the cultural and natural environment that people inherit from previous generations, as well as intangible elements like media culture (Turnpenny, 2004), religion, dances, songs, and literature (Gonzalez, 2008). Heritage is also (1) political (Allcock, 1995), (2) discursive (Wu \& Hou, 2015), (3) corrective in that it projects preferred images as counternarratives of existing representations, and (4) obvious to read in that it can present aspirational parts of history exhibited through simplified narratives that establish and confirm monological pasts, singular presents, and desired futures.

There has been an increased interest in heritage and its links to tourism, and some works have been published in the field of tourism studies to complement the research on heritage in some other related fields such as archaeology, history, culture studies, and architecture, just to name a few.

The focus has been mainly on heritage as a way of consuming heritage (Jamal \& Kim, 2005; 
Timothy \& Boyd, 2003), the management of heritage sites (Aas, Ladkin, \& Fletcher, 2005; M. Li, Wu, \& Cai, 2008; Poria, Reichel, \& Biran, 2001), the demand for (Dutta, Banerjee, \& Husain, 2007) and possibilities for developing heritage tourism (Y. Li \& Lo, 2005), its economic and social benefits (Bowitz \& Ibenholt, 2009; Del Saz Salazar \& Marques, 2005; Ruijgrok, 2006; Tuan \& Navrud, 2008), and sustainable development (Chhabra, 2009).

Significant attention has been paid to the heritage tourist (Poria, Biran, \& Reichel, 2009; Poria, Butler, \& Airey, 2001, 2004) and the authenticity of heritage experience (Chhabra, Healy, \& Sills, 2003; Ivanova, 2011; Kim \& Jamal, 2007; Poria et al., 2003; Reisinger \& Steiner, 2006), as well as heritage and nostalgia (Caton \& Santos, 2007).

The most relevant discussions for this article are those of heritage and politics (Su \& Teo, 2009) as "to speak of heritage is to speak of politics" (Allcock, 1995, p. 101). Cultural heritage tourism is a powerful source for creating and maintaining national identities (Palmer, 1999). Moreover, heritage is discursive; it is sometimes invented, suppressed, as well as linked to purposely chosen pasts, a view that has received attention from a number of scholars (Poria \& Ashworth, 2009; Wu \& Hou, 2015). Goulding and Domic (2009) even claim that representations of heritage could border on ideological manipulation. Sometimes part of the national history and cultural heritage is considered inconvenient (such as slavery and segregation in America or South Africa, the Nazi period in Germany, or communism in former socialist countries in Central and Eastern Europe), and politicians try, successfully or not, to stay away from it (Ivanov, 2009) or even actively destroy it. Another relevant theme that emerges is that of heritage and nostalgia where heritage tourism has been criticized as a glorified, misremembered past driven by nostalgia (Caton \& Santos, 2007). However, heritage tourism could be viewed not only as a way to relive past youth (in the case of heritage that is from the lived past of current generations such as communist heritage) but also a part of larger being and becoming of national identities or even as resistance to dominant narratives.

Communist heritage and its links to tourism have been researched in a more limited manner mainly as a result of its being viewed as an inconvenient part of history. Existing research has been mainly published since the 2000s and covers the communist heritage in Romania (Light 2000a, 2000b), Dujisin (2007) investigates communist sites and the tourism industry in Albania, and a number of other studies focus on the East Asian countries of North Korea, Laos, Vietnam, and Cambodia (Henderson, 2007), whereas Y. Li and Hu (2008) and Caraba (2011) discuss red tourism in China. Regarding Bulgaria, Ivanov (2009) summarizes the existing resources for communist heritage tourism in the country and proposes the way in which communist heritage could be interpreted. However, his focus is more on the management and marketing segmentation of such communist heritage sites. There isn't a clear idea of what constitutes communist heritage and what are its boundaries or discussions of where does such heritage fit in with larger national aspirations of being and becoming.

From the existing literature, it is clear that heritage is a political matter and as such the important question is that of who has the power to represent or suppress certain heritages and pasts. Tourist companies can differ from government institutions in their marketing strategies towards country's heritage commercialization and its representation (Bandyopadhyay, Morais, \& Chick, 2008). The tourism industry might be more interested in capitalizing on certain existing culture banks while governments might be more concerned with the projection of certain images. At the same time, such stark division between government and nongovernment motives in exhibiting certain heritages might not really exist but be part of the context of a national being and becoming, where many and sometimes hard to pin down agents sometimes consciously and sometimes subconsciously normalize certain views while silencing others (Horne, 1993). Tourism certainly plays an important role in what comes to be known about the past and the people. It interprets parts of their past they currently identify with; that is, tourism conveys and normalizes a specific view of nationality, inheritance, community, and common values and acts as a mediator that offers totalized narratives that can create a monological reality that comprises the normalized view of its culture and heritage (Horne, 1993; Kincheloe, 2001). As Meethan (2001) and later Hollinshead 
(2009) suggest, tourism has the power to make, demake, and remake the world, in its "creative and collaborative essentializing/normalizing/naturalizing imperatives that ordinarily and routinely run through the representational repertoire of tourism in each place" (Hollinshead, 2009, p. 639). Tourism thus becomes part of the ways in which heritage is exhibited and interpreted, favoring certain pasts while suppressing and even silencing others.

Thus, representation is a key concept in this article-representation of the past through tourism in the form of heritage.

Representation constitutes the manner through which ideas, beliefs, values, and images are both produced and provided with meaning (Shirlow, 2009). Media, advertising, tourism, photographs, and heritage as a form of exhibiting the past offer all sorts of representations of space and place and none of these mediums are value free; they communicate, often intentionally, an idea, the synthesis of ideas, and/or the nature of power relations. They are in effect the constitution of what people consider being reality or, more importantly, the imagination of reality (Barnett, 1997). Moreover, space and place themselves are no longer seen only as physical but also as "sociocultural constructions" shaped by powerful historical, political, and cultural discourses (Pritchard \& Morgan, 2001). In tourism, these powerful discourses construct and reinforce the images of tourism destinations and their attractions, which are all physical spaces but are furthermore an ideal. By the same token, destination marketing can reshape the culture and identity of places and their people. According to Shirlow (2009), who explores issues in representations regarding the "cultural turn" in geography, in many cases official representation aims to displace sections of the population from narratives of place. The same can be stated about the displacement of histories. "Official discourses of representation (state sponsored parades; national monuments) highlight the ground upon which the dominant discourses of a society are both imagined and managed" (Shirlow, 2009, p. 309). Thus, this "cultural turn" in geography and the wider appreciation of hybridity (Bhabha, 1994; Hubbard \& Kitchin, 2010; Shirlow, 2009) and heterogeneity of places and pasts as well as the contest between dominant and resistant discourses develops the notion that all forms of representation are differentiated not only by the position of the presenter and/or the viewer but also by the relationship between knowledge and space. This idea presents the opportunity to explore issues of representations of Bulgaria as a resistance to dominant Western images about Eastern Europe (New Europe) as well as the place of Bulgarian within Eastern Europe as a postcommunist country. The investigation is into the processes of heterogeneity, dominance, and resistance within the country to make/remake/demake the images of resistance/ hybridity/hybrid poetics (Huggan, 2001) as dominant representations opposing "other" perspectives. It opens a conversation about the role of communist heritage in such representations. As Shirlow (2009) points out, the process through which researchers "reinterpret the presentation of ideas and their relationship to place leads to re-articulation of those ideas and a challenge to previous constructions of meaning” (p. 311). The view is shared by Puczkó (2006), who talks about cultural tourism attractions and the need to reconsider issues of interpretations and representations not only in the light of changing social and political agendas, or the viewing of these by researchers, but also the changing needs of visitors and increasing competition. Thus, identity issues are embodied in the representation of the past and via complex and contested interpretations of what that representation means (Borja, Belil, Castells, \& Brenner, 1997; Shirlow, 2009).

Rose (1993) and Shirlow (2009) remind us that representation is a "powerful medium" through which authoritative agents and actors reproduce and enhance "preferred images," which are presented as accurate and entirely truthful (but also points out that they are not necessarily malign, devious, or untrustworthy). Cresswell (1996) expands on that by pointing out that the representation of ideas is usually accepted uncritically because many social and cultural relationships are taken for granted-thus the earlier statement that heritage can sometimes be easy to read. Thus, the study of representation is also concerned with why imagined, exaggerated, or missing representations are not challenged. Thrift (1996) argues that studying those who do not challenge what is presented to them is part of the analysis required to discover why such an apolitical approach is undertaken. In that regard, the current article attempts to explore 
the processes of marginalizing and suppressing communist/socialist heritage the context of Bulgaria to be able to outline several areas of challenging representations and point out held truths as preferred/governing ones.

\section{Methodology}

Wu and Hou (2015) propose heritage as discourse and discursive practices and discourse analysis as a methodological approach in heritage research. This article focuses on such an approach to investigating the ways communist heritage has been included or excluded from representations of Bulgaria, as well as the way communist heritage itself has been constructed.

Discourse, in the widest definition, refers to the study of language expressed through both text and conversation. However, the term discourse also has acquired differ meanings through the various historical traditions that have influenced the definition and the type of research that has been conducted. The two main approaches to discourse analysis can be said to be influenced by either ethnomethodological or Foucauldian traditions. Regardless of the influences, discourse analysis is distinguishable from strict linguistic analyses by its focus on the meaning of talk and text rather than on the linguistic organization of the components of talk such as grammar, sentence structure, and word choice. This study follows the Foucauldian tradition of discourse analysis (FDA). That means rather than exploring the rules of meaning making, FDA focuses on the power inherent in language and concentrates on understanding how historically and socially instituted sources of power make/demake/ remake the wider social world through language (Cook, 2008; Jaworski \& Pritchard, 2005). Since the mid-1990s, discourse analysis has become a contested field with the appearance of subfields such as critical discourse analysis (CDA) and the discourse analysis that follows the Foucauldian tradition has undergone changes as well. FDA has included in its focus issues of social critique and has appropriated the use of interview material as well as texts. Moreover, instead of limiting itself to decomposing the idea of individual subjectivity by looking at the institutional practices through which subjectivity and individuality are produced, FDA has shifted focus to subjectivity itself and has built in the analysis of interpretive repertoires into its approach as well as Foucault's concept of genealogical style of research. In the case of this study discourse analyses would be utilized to explore the language used by social scientists, historians, university researchers from different fields, the media, and the government to normalize certain views of traditions and subordinate and marginalize others. Through the use of documents and texts produced by authoritative agents engaged in different capacities in the tourism industry, the researcher can investigate the discourse surrounding the monological representations of heritage and the past and identify statements that would help uncover the different interpretations-both the dominant and proffered ones and subordinated/marginalized or simply downplayed ones and reflect the multivocal reality of Bulgaria.

The researcher collected data from a number of sources: images, newspaper articles, policy documents, broadcast interviews, official websites of government and nongovernment organizations, and brochures aimed at tourists, as well as several (5) historical and ethnographic texts. The sampling process is purposive-keyword search of visual and newspaper digital archives, as well as the main tourism government bodies in Bulgaria, their policy documents, and the materials produced by them. The newspapers have been chosen to be Bulgarian broadsheets and top three in terms of distribution numbers and market shares. Digital archive keyword search allows for the period examined being quite broad from 1989 to 2014. Keywords that have been used include: communist heritage, socialist monuments, socialist architecture, and socialist traditions. The search generated around 50 pieces of text where communist heritage was the main discussed issue. The focus has also been on the so named "Retro Museum" in Varna as the most significant exhibit of communist heritage to date in the country. The museum's website (including forum comments made by visitors at the time of the research-about 20), the museum's produced brochure, as well as an interview with the museum owner and promotional video have been examined through discourse/visual analyses. Because 
of difficulties of access and the focus on discourse analysis, primary interviews have not been carried out; in this regard the article is weak. However, the article identifies possible and likely interpretations as well as key players and agents in communist heritage in Bulgaria that can be expanded upon in later research.

Muncie (2006) identifies some questions to help with the identification of explicit and implicit discourses and these have been applied to all textual materials:

1. What are the conditions out of which the text emerged? What are the social, cultural, and political conditions which made the text possible?

2. What traces of other texts (intertextuality) are evident in the text?

3. How consistent, contradictory, or coherent is the text? How are contradictions managed?

4. How are people, objects, and thoughts categorized? How and what are included/excluded?

5. Who and what are viewed as normal/natural and common sense?

6. Are there any gaps, silences, or "absent presences"?

7. What is presented as legitimate/illegitimate?

8. Who are assumed to be the primary readers of the text? What assumptions are being made about the audience?

9. What are the likely social effects of the text?

10. What alternative readings might be made by different social groups?

Also, to the discourse analysis, visual analysis has been carried out on the collected images. By using visual analysis, the researcher can address issues such as who, why, and how, and in a way is doing the representations of communist heritage in the collected images (Siegesmund, 2008). The focus has been on the visual materials produced by the Retro museum as well as 10 archival photographs depicting destruction of communist symbols, sites, or restoration of communist monuments. However, the multiplicity of the meaning of images presents the researcher with some difficulties. It is still a widely held belief that images simply offer a "mirror to the world" and that images present reality, instead of interpretations of contexts of the photographer (image maker) (Crouch, Jackson, \& Thompson, 2005). In the first place, the image represents the understanding of the reality of the photographer, but the understanding changes depending on the contexts within which the images are viewed and is dependent on who is doing the viewing. Establishing the different interpretations of an image may be (and very likely is) beyond the ability of the researcher because it is not possible to encompass all interpretations and contexts.

The main line of inquiry during the analysis of the selected imagery has focused on the following main points (as informed by Siegesmund, 2008, p. 941):

- Who took the picture, composed the image?

- Where has the image been used?

- What is the perceived purpose of the image?

- How the images relate to each other?

- What is the perceived message of the image?

- How does the image relate to the text (if there is any)?

- How does the text interpret the image?

- Who is interpreting the text?

- (for video) How does the music (if there is any) relate to the images?

- What is the perceived subject of the image?

The researcher has summarized the emerging themes from the discourse and visual analysis, grouped them based on the interpreted perceptions about the subject, and then looked for dominant narratives, and in particular, timeframes. Of course, researching silences poses some difficulties. How can the researcher be sure that the identified gaps are not due to poor research approaches or poor sampling? That is one such issue. How can the researcher be sure that what she identifies as silence or suppression and marginalization is not simply her overlooking important voices in the discourse? How can the researcher be sure that she is identifying and pointing out her subjectivities and how they influence her interpretations or lack of interpretations? These are difficult questions with no easy answers. One possible approach is reflexivity on the part of the researcher and the careful application of the stated questions that do ask for the examination of alternative explanations. 


\section{Findings and Discussions}

Several major themes have been identified from the collected data. First is the attitudes towards communist/socialist heritage in Bulgaria and by Bulgarians from two broad periods, immediately after 1989 (the year of the fall of communism in Bulgaria) to roughly 2005-2010.

It is hard to pinpoint the year when particular attitudes started to change but after 2005 different views on communist heritage have been expressed. Although in the first period the major emerging themes are predominantly those of silencing, suppression, and even destruction of communist heritage, after 2000-2005 communist heritage has been reevaluated, monuments have been repaired, and exhibits and a museum have opened doors to capture the emerging sense of nostalgia. Of course, the discourse regarding that time of Bulgarian history, its exhibit, and its inclusion in representational images from the tourism industry is more complicated as the data show. Another major theme that emerged about communist heritage is its strong divisive nature in the national discourse. An important theme that has been identified is what is and what is not considered communist heritage and who is doing the defining.

\section{Communist Heritage and Destruction: The First Period}

The fall of communism brought about a significant change in every aspect of the Bulgarian society (Andreev, 2007). There has been a perceived drastic, even cataclysmic, change in the political, economic, social, and cultural life of the country. In the years immediately after the changes, there has been a feeling of utter break up with the communist past, a denial of everything achieved during those years, and a strong view that today's society has nothing valuable to learn or persevere from these years. Most symbols of the communist past have been eradicated (see Figs. 1 and 2 for the destruction of significant symbols of communism) and those 45 years have been viewed (among the general public) as years of humiliation and terror:

The communism here (in Bulgaria) was enforced with repressions and terror, that not many of the other Eastern European countries experienced.
Thousands killed with and without lawful due process, and the suffering of the 185,000 Bulgarians send to the concentrations camps of communism were the price, that our country paid for her communisation. (Taken from the speech of President Petar Stoyanov during the welcoming of US President William Clinton, November 22, 1999)

The heritage in the form of ideology and the traditions (customs, music, and rituals) have been imported (in conscious attempts from the Communist party, something that has already been referred to by the researcher in the examples taken from the Communist propaganda archive, as well as the agendas and aims of the ethnographers as described in the Introduction to the most authoritative study of Bulgarian tradition-Ethnography of Bulgaria, 1980) from abroad (Soviet Union), invented, and unauthentic, and had be scraped. The architecture of the buildings, monuments, and arts have been perceived in the rhetoric of the public discourse as having no aesthetic merit:

Based on an old logic, or elementary protective
reflex, that is well known to social psychologists,
the party apologists of these monuments easily
leave behind their class understandings and claim
them (the monuments) not as their own, class party,
but national deed and achievement. Today they
carefully avoid mentioning even with two words
their (the monuments) party- propaganda func-
tions and goals, the only justification for their cre-
ation, and underline only their "artistic" meaning,
which has always been suspect, and as we will see
later (further in the article) rotten at their very birth.
(Prof. Dimitar Angelov in an article published by
Vek Newspaper, September 2, 1992)

The only valuable elements are those folk traditions that have survived from before communism. The bodies of collected and written Bulgarian traditions such as Ethnography of Bulgaria and other similar collections, first out of lack of materials to replace them in the teaching of Bulgarian tradition in universities (Ethnography of Bulgaria is still part of the History program at Sofia University) but later because of their perceived merits still remain the leading collections of Bulgarian tradition: "my focus on the ideological and political constraints should in no way bear prejudice to the descriptive ethnographic record which, in my opinion, at least, remains admirable” (Hadjinikolov, 2003). 


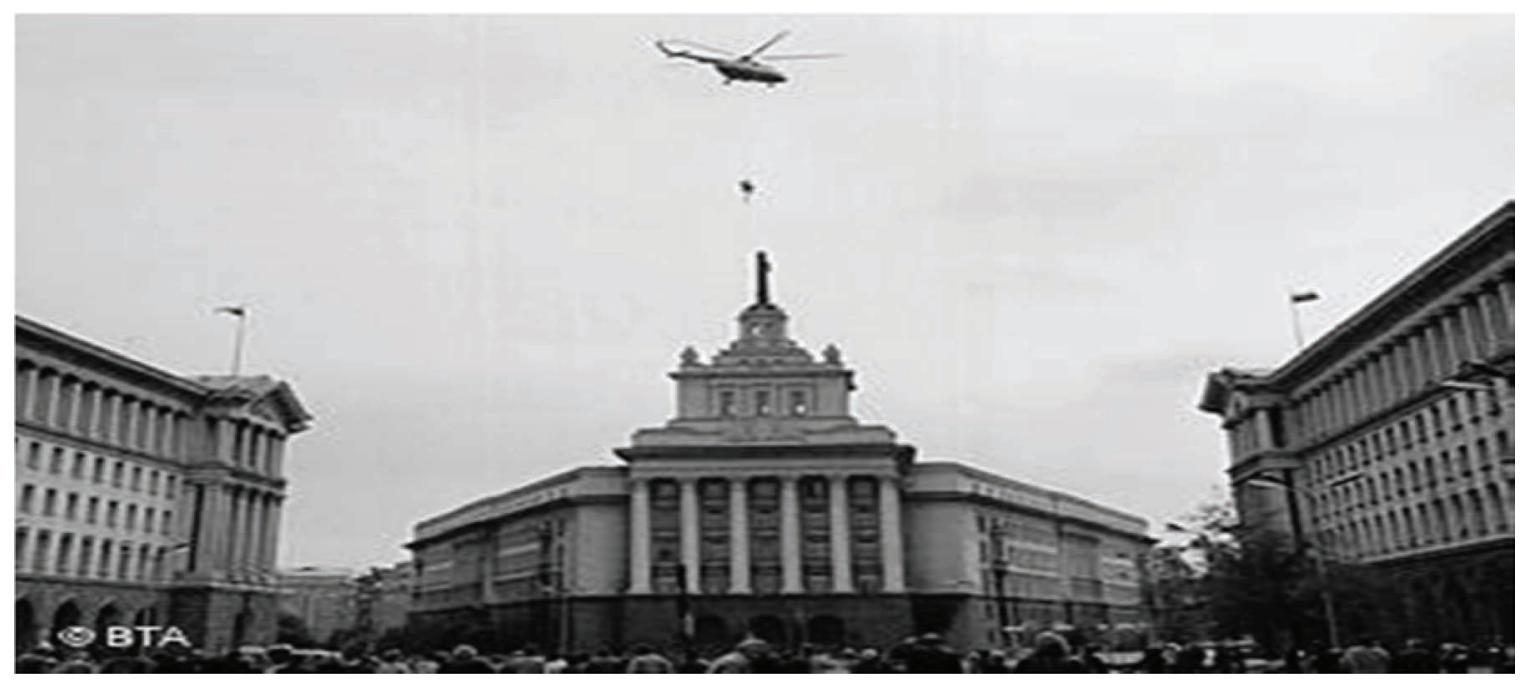

The Removal of the Red Star from the Communist party Headquarters, 1990 (copyright of the Bulgarian News Agency, BTA)

Possible interpretations established by the researcher of this image include [based on the examination of the media (both paper and electronic) publications and discourses]:

1. The fall of the Communism in Bulgaria (Demokratzia newspaper, Deuitche Welle 1991-2001)

2. The triumph of the democratic will of the people in Bulgaria (Demokratzia newspaper, Deuitche Welle 1991-2010)

3. Necessary destruction of the communist heritage (BNT, 2009, stories about 10th on November)

4. Unnecessary destruction of the communist heritage (Tema Magazine 2006, Monitr, 2009)

5. The unknown faith of the red star (Tema Magazine, 2006)

Figure 1. The meanings of images are context dependent and are by no means fixed. One image offers the interpretation of the perceived reality of the image taker, his conscious intention (but also in many instances subconscious, unintended conveyed meanings) to convey certain ideas to the viewers. The interpretations of the viewers would depend on their understandings of the world and the contexts within which they are interpreting the image.

The general desire for this seemingly complete severance with the past ideology could be seen in the Removal of the Five Pointed Red Star from the Bulgarian Communist Party Headquarter (Fig. 1)-a symbol of communism and Soviet Russia, and the destruction of the mausoleum of the first Bulgarian communist leader Georgi Dimitrov. Of course, the seeming desire for complete severance is not as complete (and probably never can be) as can be seen from the quotes in Figure 1. There are voices that desire the protection of the communist heritage even in the years immediately after the changes, but they seem to be the minority-many (if not most) monuments have been destroyed, and the remaining ones are still a thorny issue in the public discourse.

\section{Communist Heritage and Nostalgia: Second Period}

Today the communist heritage remains a largely divisive and contested issue. Regarding images of this heritage to represent Bulgaria in general and for the purposes of tourism, despite the interest of the Western tourist, the communist past remains mostly silent, a marginalized and forgotten part of the history in terms of tradition and culture:

November 10, 1989 turned out to be a crossroad not only in the Bulgarian history but also for our collective memory. The exhilaration to destroy the old used to grip the whole country during the first years after the change. The monuments from the 


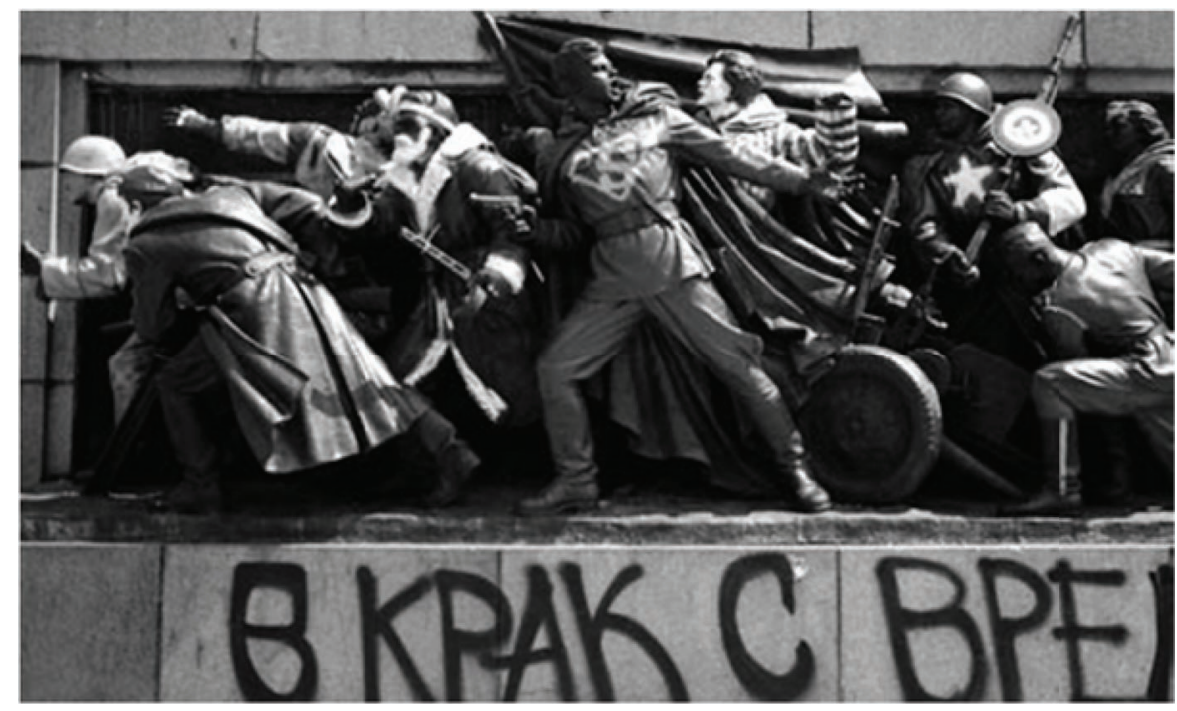

Sofia's communist war monument after a colorful makeover replacing troops with Superman, Robin, Santa, and Ronald McDonald. Photograph: Stoyan Nenov/Reuters; the text underneath the monument reads "In step with time" (picture taken from The Guardian, June 22, 2011; https://www.theguardian.com/world/2011/jun/22/russia-red-army-memorialpainted)

Who took the picture, composed the image? Although the author of the picture is named, nothing else is known about him; his interpretation is not obvious to the researcher, apart from his consideration that the repainting of the monument is significant to be photographed.

Where has the image been used? In this case the image has been used in a Guardian article about Moscow's displeasure with the defacing of the Soviet Red Army War memorial ("Russia not amused at Red Army statue re-invented as Superman and friends," The Guardian, June 22, 2011; https://www.theguardian.com/world/2011/jun/22/russia-red-armymemorial-painted).

What is the perceived purpose of the image? The perceived (by the researcher) purpose of the picture is to illustrate the text of the article and demonstrate to the English public why Russia has been displeased. The inclusion of the artists' original inscription on the memorial (that in the article has been translated into English) also gives the researcher the impression that at least one purpose is to show the changing realities in the formal communist country and the replacement of one kind of dominance over Bulgaria (Soviet) with another (American). The purpose of the image is hard to understand outside of the context-it has been published in a newspaper in Britain where the intended conscious purpose is not to inform the public that there are artists in Bulgaria for example (which is certainly an interpretation). Another perceived purpose is to confirm the existing expectations that Russia still feels threatened by the Western cultural and social interpretations and their establishments in her previous? spheres of influence.

How the images relate to each other? There are no other images in the article.

What is the perceived message of the image? This is where it gets tricky again. There is no one message- the messages and interpretations of what the image says is strongly dependent on who is doing the interpretations. The newspaper interpretations are accessible through the article and text that accompany the image, so they will be discussed in the text and image sections.

The author's messages are not available beyond it is a significant event that should be documented (that is known to the researcher from the very act of the image taking).

The image illustrates the intention of the author of the painting of the monument through the inclusion of capitation to his work - the changing realities in Bulgaria. The author of the picture seems to agree, based on the inclusion of the capitation in the picture (of course that is as perceived by the researcher; maybe the photographer decided to include it because it was part of the "artwork" - these are not available to the researcher beyond her interpretation based on the inclusion of the capitation).

The researcher can interpret the image and its subject as a commentary on the changing realities in Bulgaria, on the notion of dominance and subjugation of Bulgaria between Russia and the States, an illustration of the differences between the dominations-imposed through military might, and imposed through (mainly) cultural means in Bulgaria, the changing notion of heroism, the new, emerging traditions in Bulgaria influenced by Russia (the Soviets) before, and by the Americanization now, the globalization effects in Bulgaria, the strong emotions of the Soviet period heritage in Bulgaria, arriving at an interpretation is the death of interpretation (Hollinshead, 2007). 


\begin{abstract}
The perceived message of the image depends on who is doing the interpretation!
How does the image relate to the text (if there is any)? The image is illustrative of the text's interpretation but at the same time invites other interpretations (maybe unintended — such as there are artists in Bulgaria, the American culture is important in Bulgaria, and many others). It is at the beginning of the article, although beneath the title, that already offers a ready to use interpretation.

How does the text interpret the image? The title suggests that it is Russia that is more important (and not so much Bulgaria, where the event took place); there is a hint at the overreaction of Russia to the event:

“There was Superman in red leather boots, Ronald McDonald clutching a bottle of beer, and Santa Claus about to look through a pair of binoculars.

A benign if motley bunch, you may think. But they were enough to provoke an international diplomatic rebuke, it emerged on Wednesday, after they featured in an impudent make-over of a Soviet war memorial. Members of Russia's government were said to be seething" (The Guardian, June 22, 2011; https://www.theguardian.com/world/2011/jun/22/russia-redarmy-memorial-painted)

Who is interpreting the text? The researcher is the one interpreting the text and looking for the possible interpretations of The Guardian author's position through the language used, as well as other included interpretations in the text through the inclusion of quotations. For example, the author of the repainting of the monument for The Guardian journalist (Tom Parfitt, based in Moscow, which confirms that the interest in not so much in Bulgaria where the event took place but about Russia and her reaction) is an "artist," while for the Russians, he is a "vandal," and for the Bulgarian police (quoted in the article)—a "culprit."

(for video) How does the music (if there is any) relate to the images? Not a video, no music, or speech.

Figure 2. This example of interpreting an image is by no means exhaustive. It is obvious that the issues that can and should be looked at are numerous, and within the context of the methodology of this study and the sheer amount of data available (and collected), the researcher has to make judgements on what to include. Visual analysis in this study is used in a supporting role to discourse analysis and the collected and present images are used to demonstrate and substantiate certain claims and analysis the researcher makes. In the case of this picture the claim is that Communist heritage and its place in contemporary Bulgaria is still a very much contested issue.
\end{abstract}

totalitarian era are hated and respected at the same time. During those 21 years after the change, many of them are destroyed, painted with swastikas and curse words and degrading images. With the passing of time and especially after the demolition of the mausoleum of Georgi Dimitrov in 1999, the passions died down. Not everywhere, though. (Taken from "Monuments With Murky Fortune," Trud Newspaper, May 6, 2011)

In the past 5 years, to the writing of this article (in 2015), there seem to be different understandings emerging. Faced with the hardships of the transitional years, people are becoming nostalgic about the communist era and new narratives begin to emerge. Views about the accomplishments of this era are beginning to emphasise the positives and beneficial achievements (as nostalgia for modernity, Roy, 2003) and the subsequent destruction:

That which is laid in the seaside tourism is being destroyed; we need to work to improve it. ... The foreign tourists seek clean air, tranquility, peace. When I went to Golden Sands in 1956-1957, the whole forest was a concert hall, birds singing everywhere. Look what we did with Bansko toothe same overbuilding. (Petar Dojtchev, 2013, Nova TV)
Despite these understandings becoming more prominent in the public discourse, representations of that part of the Bulgarian heritage are still limited. This view is changing with the opening of the socalled "Retro Museum" in Varna. The museum is described in the official visitor guide of Varna (producer by Varna Municipality) as "the whole life from the time of socialism.” The museum includes exhibits from the period 1944-1989, which are telling in artifacts how Bulgarians lived under socialism. Bulgarian cigarettes without a filter, Russian vacuum cleaners, household from East Germany, Polish cosmetics, and most desirable cars produced in the former Communist countries. The museum is founded by the businessman Tsvetan Atanasov. It also features a collection of over 50 cars from the era: "The Volga," "Moskvich," "Skoda," and "Trabant," to name a few. Special emphasis in the collection of the museum are the wax figures of great personalities of the era like Todor Zhivkov, Leonid Brezhnev, and Fidel Castro, but also people favorites as Emil Dimitrov, Georgi Partsalev, George Kaloyanchev, and Todor Kolev (Bulgarian artists from the period).

The public received the museum well with many positive messages from visitors such that they find 
the exhibit "unique” with a huge "sentimental value for the people that lived during that time," "every exhibit returns us to our happy childhood." The strong sense of nostalgia is easy to uncover. In an interview for Hobby TV, the owner of the museum explains that the museum is his reflection of the communist period and that for him this period has been happy, secure, and prosperous. He does acknowledge that other people might have had different experiences, but that is not reflected in the exhibit. The museum is targeted at people who want to relive their youth but also to young people that want to learn about how their parents lived and to foreign tourists-Varna is one of the hubs for summer holiday tourists and brochures in English are distributed in most of the resorts catering to them. The museum does include the exhibit themes identified by Ivanov (2009) but does ignore the final one of "The dark side of communism-a section concentrated on the censorship, concentration camps from the early years of communist regime, political murders, huge foreign debt, and environment polluting plant” (p. 190). The museum presents the period as "The Golden Age" of Bulgaria (as one visitor) terms it. This representation is very one sided and it demonstrates the strong emotions that this heritage still elicits-from destruction to glorification-where the aim is to relive a "glorified misremembered version of the past" (Caton \& Santos, 2007, p. 371). Both lack subtlety and multivocality and aim to normalize certain views of the period in a very monolgic reality. However, it is not hard to see this development as a response and as a resistance to the first period in attitudes towards communist heritage that sought to erase it from the past and images of the new European and democratic country.

During the early years, the drive to suppress and silence communist heritage came from the political parties in power, the government sanctioned by the Parliament and with more or less popular support. It can be viewed as an expression of a strong desire to forge new democratic parties, but also to unequivocally demonstrate by government and political members their belonging to the dissident movement and the new Western-oriented politics. In this more nostalgic period those more positive representations and exhibitions are conveyed mostly by private organizations in the tourism industry but with the tacit approval of local governmental organizations, visible by the inclusion of the museum in the official guides produced by local governmental tourism and marketing organizations.

It is also necessary to point out that during both periods there are dissenting voices that can be heard in the discourse, commentators that caution against the destruction of the communist heritage (see Figs. 1 and 2), and commentators that point out the dangers of nostalgia and call for a more balanced approach to communist heritage and how it is exhibited. However, the dominant discourse can be clearly identified as well as the changing dominant understandings of the period.

An often overlooked topic in the publications on Communist heritage seems to be that of what exactly constitutes communist heritage-what heritage from that period is communist and what is not. There is not a particular definition of what that heritage is and is not apart from that which is instantly recognized as belonging to that periodovertly related to the communist party and the way of life from 1945 to 1989 (for Bulgaria). However, there are a lot of heritages and representations that although produced or emerged during that time are not considered communist/socialist.

For example, Bulgaria as a sun, sea, and sand destination is considered to be a postcommunist representation of the country as a tourist destination. However, "Bulgaria emerged on the international tourism market in the 60 s as a typical sun, sea and sand destination” (Bachvarov, 1998, p. 43).

Many of the traditions viewed as authentic and truly Bulgarian have been codified and invented during the communist period. For example, the famous traditional food "Shopska Salata" is being claimed as invented by Balkanturist to attract foreign tourists to the international resorts during socialism (Petar Dojchev, the head of "Balkanturist") as well as many other images of Bulgarian tradition. Those who are interested in exploring the roots of Bulgarian tradition represented in tourism should look at Ivanova (2011) on the representations of traditionality, and transitionality in Kozak (2011). These heritages are considered only "polluted," and communist interpretations of them can be "purged" and their "true" meaning reinstated. However, as 
the above study concludes, they are just as much socialist/communist/modern heritage as those artifacts exhibited in the "Retro Museum."

\section{Conclusion}

This article focuses on the suppression and silencing heritage in postcommunist Bulgaria and explores the contested nature of heritage, the multivocality (or lack of) in its representations, and the power dynamic in the normalizations of certain views of the past. After the end of the Communist era, Bulgaria faces the need to define itself, find its image, separate from the Cold War ideas about it is part of the ComIntern (International Communism), the Soviet Union's closest ally, “enemy” to the West. The need is as much for changing the ideas of the outside world (something that can be seen from the stated desire in the Bulgarian symbols initiatives, for example) as it is to find its meaning and belonging. Words such as "transitional," "democracy," "market economy," "crisis," and "privatizations" describe the political and economic aspirations and processes of the country, while in social and cultural terms the words seem to be "not communist" but also in the last 10 years "positive image."

Initially, the exhilaration of the newly achieved freedom and the access to Western (American) culture is quickly followed by the fear that one social and cultural hegemony is being replaced by another. This fear certainly informs part of the drive towards the creation of a new, different image of Bulgaria (something that is always talked of in a singular form). Another strong drive is to counter the negative images of Bulgaria in the West-former Soviet country, ripe with poverty, corruption, economic crisis, unemployment, broken society, but also to rediscover and appreciate its history and culture. Lately, with the membership in the EU and the strong criticism and feeling that Bulgaria is not ready for it, the latter two are becoming the strong driving forces. The question seems to be what does Bulgaria have apart from the communist culture and heritage? The answer seems to be to return to the time before Communism and to reexamine and keep what is deemed traditional Bulgarian from the Bulgarian kingdoms and the National Revival, the Liberation, and the years leading to the Second
World War, where Bulgaria has been more or less a major player on the European stage, or following and developing in a modern European way something that has been cut with the Communist era. That desire has led to the suppression, marginalization, and even destruction of the perceived communist heritage, a symbolic rejection of the ideas of socialism and the Soviet hegemony, replaced by the narrative of the liberation from an oppressive regime. Tourism has played an important role in the creation and normalization of the new European identity and the silencing of the socialist past of the country.

However, as Foucault reminds us to be wary of grand narratives and actions, especially those taken in the name of liberation, the silencing and solely negative portrayal of that period coupled with the hardships and disillusionment of the transitional and posttransitional period gives rise to resistance in the form of competing narratives of nostalgia, of happy and secure life, of new appreciation of the communist period, and the inclusion of its heritage in representations and what comes to be known of Bulgaria. However, it is not useful to view communist/socialist heritage as only dichotomous, either silenced and suppressed or embraced and sanitized. Defining communist heritage itself is not an easy task and what constitutes communist heritage in the first place is porous, political, and perceptual. Heritage (whether it is communist or other) itself is an act of representation; it is history made manifest and present, a sanctioned timeline of national being that is acknowledged and valued. It is interpreted through the favored political discourse and its borders drawn to reflect the national ideas of becoming. As such it is narratives and ideas about the heritage and its borders that are silenced and marginalized and dominant discourses emerge.

Communist heritage has proven to be a thorny issue for postcommunist countries in general and Bulgaria in particular. Although narratives are battling for dominance, it has been hard for tourism to embrace the perceived communist heritage and exhibit it as touristic images and sites. The establishment of a more stable preferred narrative has been the turning point of exclusion/inclusion of the communist heritage in tourism. Despite the dominance 
of the more nostalgic positive representations of the heritage, the darker aspects of the regime are included although in a more marginalized fashion. It seems that the tourism industry is becoming more comfortable with notions of challenged narratives and exhibiting contradicting visions and images as long as they are established and certain, and easy to read. Thus, the findings of the study are consistent with the reviewed literature in terms of the politics of heritage but they problematize the notion of communist heritage, look at nostalgia and heritage as resistance, and somewhat develop the notion of representation through and in tourism as more tolerant of plurality but not uncertainty and including contradicting narratives as long as they are easy to read. The power dynamic in this case plays out as an expression of national aspirations and resistances to what is perceived to be outside visions and framing of the country but also as a response to the internal challenges of the 21st century Bulgaria, an emerging resistance to a new dominant narrative at the heart of governmental institutions where privately run communist heritage tourism sites voice alternative views of the past.

Communism and Socialism are significant and influential parts of Bulgarian history - the heritage of that period should be exhibited but done so in ways to account for the different experiences of the people and diversity of interpretations. Solely negative or positive interpretations silence significant numbers of experiences and marginalize groups of people and inheritances, as well as lived experiences, they present sanitised versions of history and the tourism and related creative industries need to take care in what they convey and normalize and allow for the messy, difficult realities to be reflected in the heritages that are accessible. In this regard developments of red tourism need to learn from what has been done in many dark tourism sites and be more sensitive of the multivocality of history and heritage and as Caton and Santos (2007) suggest, communist heritage does not have to be driven solely by nostalgia.

\section{References}

Aas, C., Ladkin, A., \& Fletcher, J. (2005). Stakeholder collaboration and heritage management. Annals of Tourism Research, 32(1), 28-48.
Allcock, J. (1995). International tourism and the appropriation of history in the Balkans. In M-F. Lanfant, J. B. Allcock, \& E. M. Bruner (Eds.), International tourism: Identity and change (pp. 100-112). London: Sage.

Anderson, P., Wiessala, G., \& Williams, C. (2000). New Europe in transition. London: Frances Pinter Publishers Ltd.

Andreev, S. A. (2007). The unbearable lightness of membership: Bulgaria and Romania after the 2007 EU accession. Communist and Post-Communist Studies, 42(3), 375-393.

Bachvarov, M. (1997). End of the model? Tourism in postcommunist Bulgaria. Tourism Management, 18(1), 43-50.

Baeva, I., \& Kalinova, E. (2003). The Bulgarian transitions. Sofia, Bulgaria: Prosveta.

Bandyopadhyay, R., Morais, D. B., \& Chick, G. (2008). Religion and identity in India's heritage tourism. Annals of Tourism Research, 35(3), 790-808.

Barnett, J. (1997). Reclaiming security. Peace Review, 9(3), 405-410.

Benovska-Sabkova, M. (2001). The political transitions of the everyday culture. Sofia, Bulgaria: Marin Drinov.

Bhabha, H. K. (1994). The location of culture. London: Routledge.

Bianchi, R. V. (2002). Towards a new political economy of global tourism. In R. Sharpley, \& D. Telfer (Eds.), Tourism and development concepts and issues (pp. 265-300). Clevedon, UK: Channel View Publications.

Brzezinski, Z. (1993). The Soviet political system: Transformation or degeneration. New York: Irvington Publishers.

Borja, J., Belil, M., Castells, M., \& Benner, C. (1997). Local and global: The management of cities in the information age. London: Earthscan Publications.

Bojkov, V. D. (2004). Neither here, not there: Bulgaria and Romania in current European politics. Communist and Post-Communist Studies, 37(4), 509-522.

Bowitz, E., \& Ibenholt, K. (2009). Economic impacts of cultural heritage-Research and perspectives. Journal of Cultural Heritage, 10(1), 1-8.

Boyd, S. (2002). Cultural and heritage tourism in Canada: Opportunities, principles and challenges. Tourism and Hospitality Research, 3, 211-233.

Caton, K., \& Santos, C. A. (2007). Heritage tourism on Route 66: Deconstructing nostalgia. Journal of Travel Research, 45(4), 371-386.

Caraba, C. C. (2011). Communist heritage tourism and red tourism: Concepts, development and problems. Cinq Continents, 1(1), 29-39.

Chhabra, D. (2009). Proposing a sustainable marketing framework for heritage tourism. Journal of Sustainable Tourism, 17(3), 303-320.

Chhabra, D., Healy, R., \& Sills, E. (2003). Staged authenticity and heritage tourism. Annals of Tourism Research, 30(3), 702-719.

Cook, K. E. (2008). Discourse. In L. M. Given (Ed.), The Sage encyclopedia of qualitative research. (pp. 217220). London: Sage. 
Cresswell, T. (1996). In place-out of place: Geography, ideology, and transgression. Minneapolis, MN: University of Minnesota Press.

Crouch, D., Jackson, R., \& Thompson, F. (Eds.). (2005). The media and the tourist imagination. London: Routledge.

Del Saz Salazar, S., \& Marques, J. M. (2005). Valuing cultural heritage: The social benefits of restoring and old Arab tower. Journal of Cultural Heritage, 6(1), 69-77.

Dujisin, Z. (2007). Forget communism . . . or sell it. Retrieved from http:/www.global-perspectives.info/ download/2007/pdf/ausgabe_08-09_07.pdf

Dutta, M., Banerjee, S. \& Husain, Z. (2007). Untapped demand for heritage: A contingent valuation study of Prinsep Ghat, Calcutta. Tourism Management, 28(1), 83-95.

Frusetta, J., \& Glont, A. (2009). Interwar fascism and the post-1989 radical right: Ideology, opportunism and historical legacy in Bulgaria and Romania. Communist and Post-Communist Studies, 42(4), 551-571.

Gandhi, L. (1998). Postcolonial theory: A critical introduction. Edinburgh, Scotland: Edinburgh University Press.

Goulding, C., \& Domic, D. (2009). Heritage, identity and ideological manipulation: The case of Croatia. Annals of Tourism Research, 36(1), 85-102.

Gonzalez, M. V. (2008). Intangible heritage tourism and identity. Tourism Management, 29(4), 807-810.

Hadjinikolov, V. (Ed.). (1980). Ethnography of Bulgaria. Sofia, Bulgaria: Prosveta.

Hadjinikolov, V. (Ed.). (2003). Ethnography of Bulgaria revised. Sofia, Bulgaria: Prosveta.

Harrison, D. (1993). Bulgarian tourism: A state of uncertainty. Annals of Tourism Research, 20(3), 519-534.

Henderson, J. C. (2007). Communism, heritage and tourism in East Asia. International Journal of Heritage Studies, 13(3), 240-254.

Hollinshead, K. (1997). Heritage tourism under postmodernity: Truth and the past. In C. Ryan (Ed.), The tourist experience (pp. 170-193). London: Cassell.

Hollinshead, K. (2009). Tourism and the social production of culture and place: Critical conceptualisations on the projection of location. Tourism Analysis, 13, 639-660.

Horne, D. (1993). The intelligent tourist. Sydney: Margaret Gee Publishing.

Hubbard, P., \& Kitchin, R. (Eds.). (2010). Key thinkers on space and place. London: Sage.

Huggan, G. (2001). The postcolonial exotic: Marketing the margins. London: Routledge.

Ivanov, S. (2009). Opportunities for developing communist heritage tourism in Bulgaria. Turizam: znanstvenostručni časopis, 57(2), 177-192.

Ivanova, M. (2011). Representations of Bulgaria in and through tourism: The dynamics of traditionality visa-vis transitionality. In M. Kozak \& N. Kozak (Eds.), Sustainability of tourism: Cultural and environmental perspectives (pp. 110-135). Newcastle upon Tyne, UK: Cambridge Scholar Publications.
Jack, G., \& Phipps, A. (2005). Tourism and cultural exchange: Why tourism matters. Clevedon, UK: Channel View Publications.

Jamal, T., \& Kim, H. (2005). Bridging the interdisciplinary divide: Towards an integrated framework for heritage tourism research. Tourist Studies, 5(1), 55-83.

Jaworski, A., \& Pritchard, A. (Eds.). (2005). Discourse, communication and tourism. Clevedon, UK: Channel View Publications.

Kim, H., \& Jamal, T. (2007). Touristic quest for existential authenticity. Annals of Tourism Research, 34(1), 181-201.

Kincheloe, J. L. (2001). Describing the bricolage: Conceptualizing a new rigor in qualitative research. Qualitative Inquiry, 7, 679-692.

Kozak, M., \& Kozak, N. (Eds.). (2011). Sustainability of tourism: Cultural and environmental perspectives. Newcastle upon Tyne, UK: Cambridge Scholars Publishing.

Lanfant, M., Allcock, J., \& Bruner, E. M. (Eds.). (1995). Identity and change. London: Sage.

Lavigne, M. (2000). Ten years of transition: A review article. Communist and Post-Communist Studies, 33(4), 475-483.

Li, M., Wu, B., \& Cai, L. (2008). Tourism development of World Heritage Sites in China: A geographic perspective. Tourism Management, 29(2), 308-319.

Li, Y., \& Hu, Z. (2008). Red tourism in China. Journal of China Tourism Research, 4(2), 156-171.

Li, Y., \& Lo, L. B. R. (2005). Opportunities and constraints of heritage tourism in Hong Kong's changing cultural landscape. Tourism and Hospitality Research, 5(4), 322-345.

Light, D. (2000a). An unwanted past: Contemporary tourism and the heritage of communism in Romania. International Journal of Heritage Studies, 6(2), 145-160.

Light, D. (2000b). Gazing on communism: Heritage tourism and post-communist identities in Germany, Hungary and Romania. Tourism Geographies, 2(2), 157-176.

McNeill, D. (2004). The new Europe: Imagined spaces. London: Hodder Arnold Publication.

Meethan, K. (2001). Tourism in global society: Place, culture, consumption. Basingstoke, UK: Palgrave.

Ministry of Economy, Energy and Tourism. (2007). General observations and behaviour. Retrieved from http://www. tourism.government.bg/en

Muncie, J. (2006). Discourse analysis. In V. Jupp (Ed.), The Sage dictionary of social research methods (pp. 74-76). London: Sage.

Palmer, C. (1999). Tourism and the symbols of identity. Tourism Management, 20(3), 313-321.

Pearlman, M. V. (1999). Conflicts and constraints in Bulgaria's tourism sector. Annals of Tourism Research, 17(1), 103-122.

Poria, Y., \& Ashworth, G. (2009). Heritage tourism—current resource for conflict. Annals of Tourism Research, 36(3), 522-525.

Poria, Y., Biran, A., \& Reichel, A. (2009). Visitors' preferences for interpretation at Heritage sites. Journal of Travel Research, 48(1), 92-105. 
Poria, Y., Butler, R., \& Airey, D. (2003). The core of heritage tourism. Annals of Tourism Research, 30(1), 238-254.

Poria, Y., Butler, R., \& Airey, D. (2004). Links between tourists, heritage, and reasons for visiting heritage sites. Journal of Travel Research, 43(1), 19-43.

Poria, Y., Reichel, A., \& Biran, A. (2001). Heritage site management: Motivations and expectations. Annals of Tourism Research, 33(1), 162-178.

Pritchard, A., \& Morgan, N. J. (2001). Culture, identity and tourism representation: Marketing Cymru or Wales? Tourism Management, 22(2), 167-179.

Puczkó, L. (2006). Interpretation in cultural tourism. In M. Smith \& M. Robinson (Eds.), Cultural tourism in a changing world: Politics, participation and (re) presentation (pp. 227-243). Clevedon, UK: Channel View Publications.

Reisinger, Y., \& Steiner, C. J. (2006). Conceptualizing object authenticity. Annals of Tourism Research, 33(1), 65-86.

Rose, G. (1993). Feminism \& geography: The limits of geographical knowledge. Minneapolis, MN: University of Minnesota Press.

Roy, A. (2003). Nostalgias of the modern. In N. Al Sayyad (Ed.), The end of tradition? (pp. 63-86). London: Routledge.

Ruijgrok, E. C. M. (2006). The three economic values of cultural heritage: A case study in the Netherlands. Journal of Cultural Heritage, 7(3), 206-213.

Shirlow, P. (2009). Representation. In C. Gallaher, C. Dahlam, A. Mountz, \& P. Shirlow (Eds.), Key concepts in political geography (pp. 235-246). London: Sage.
Sibley, D., Jackson, P., Atkinson, D., \& Washbourne, N. (Eds). (2005). Cultural geography: A critical dictionary of key concepts. New York: I. B. Tauris.

Siegesmund, R. (2008). Visual research. In L. M. Given (Ed.), The Sage encyclopaedia of qualitative research methods (pp. 843-845). Thousand Oaks, CA: Sage.

Smith, A. (2002). Imagining geographies of the "new Europe": Geo-economic power and the "new” European architecture of integration. Political Geography, 21(5), 647-670.

$\mathrm{Su}, \overline{\mathrm{X} .,}$ \& Teo, P. (2009). The politics of heritage tourism in China: A view from Lijiang. London: Routledge.

Timothy, D., \& Boyd, S. (2003). Heritage tourism. Harlow, UK: Prentice Hall.

Theobald, W. F. (2005). Global tourism (3rd ed.). Amsterdam: Elsevier.

Thrift, N. (1996). Spatial formations (Vol. 42). London: Sage.

Tuan, T. H., \& Navrud, S. (2008). Capturing the benefits of preserving cultural heritage. Journal of Cultural Heritage, 9(3), 326-337.

Turnpenny, M. (2004). Cultural heritage, an ill-defined concept? A call for joined-up policy. International Journal of Heritage Studies, 10(3), 295-307.

Venn, C. (2006). The postcolonial challenge: Towards alternative worlds. London: Sage.

Wu, Z., \& Hou, S. (2015). Heritage and discourse. In E. Waterton \& S. Watson (Eds.), The Palgrave handbook of contemporary heritage research (pp. 37-51). Basingstoke, UK: Palgrave Macmillan. 
Copyright of Tourism Culture \& Communication is the property of Cognizant, LLC and its content may not be copied or emailed to multiple sites or posted to a listserv without the copyright holder's express written permission. However, users may print, download, or email articles for individual use. 